\title{
EVALUATION OF SUPPLIERS UNDER UNCERTAINTY: A MULTIPHASE APPROACH BASED ON FUZZY AHP AND FUZZY EDAS
}

\author{
Željko STEVIĆ ${ }^{1^{*}}$, Marko VASILJEVIĆ², Adis PUŠKA ${ }^{3}$, Ilija TANACKOV ${ }^{4}$, \\ Raimundas JUNEVIČIUS ${ }^{5 \#}$, Slavko VESKOVIĆ 6 \\ ${ }^{1,2}$ Faculty of Transport and Traffic Engineering Doboj, University of East Sarajevo, Doboj, Bosnia and Herzegovina \\ ${ }^{3}$ Institute for Scientific Research and Development, Brcko District, Bosnia and Herzegovina \\ ${ }^{4}$ Faculty of Technical Sciences, University of Novi Sad, Novi Sad, Serbia \\ ${ }^{5}$ Dept of Mobile Machinery and Railway Transport, Vilnius Gediminas Technical University, Vilnius, Lithuania \\ ${ }^{6}$ Faculty of Transport and Traffic Engineering, University of Belgrade, Belgrade, Serbia
}

Received 21 December 2017; revised 28 March 2018, 17 April 2018; accepted 1 July 2018

\begin{abstract}
A decision-making process requires a prior definition and fulfilment of certain factors, especially when it refers to complex fields such as supply chain management. One of the most important items in the initial stage of a supply chain, which strongly influences its further flow, is making a decision on the most suitable supplier. In this paper, a model for evaluation and supplier selection has been proposed, which has been considered in more than ten different production areas. The model consists of twenty quantitative and qualitative criteria, which are reduced to a total of nine by the application of the fuzzy AHP and the assessment of managers in production companies. The verification of the model has been presented throughout a selection of suppliers in a company for the production of plastic bags and foils, where the Fuzzy Analytic Hierarchy Process (Fuzzy AHP) method has been used to determine the significance of the criteria, and the Fuzzy Evaluation based on Distance from Average Solution (Fuzzy EDAS) to evaluate and select suppliers. The obtained results have been considered throughout a sensitivity analysis in which a total of 15 different scenarios have been formed and where the stability of the model has been determined, since the supplier one is the best solution in all the cases.
\end{abstract}

Keywords: supply chain, supplier selection, multi-criteria decision-making, Fuzzy AHP, Fuzzy EDAS, logistics.

\section{Introduction}

According to Jafarnejad and Salimi (2013), the success of an entire supply chain largely depends on the selection of suppliers, while authors of the paper (Singh et al. 2012) point out that the process of supplier selection is one of the most significant factors, which has a direct impact on an organization's performance. Modern supply chains require the fulfilment of very strict requirements, so a very difficult task is set before purchasing system managers in terms of properly evaluating potential suppliers that will enable efficient production and the formation of the final price for the product with which the company will be competitive in the marketplace. In addition to the set of criteria for evaluating suppliers, it is necessary to have experience and knowledge related to supplier evaluation methods. The policy of relation and evaluation of supply sources has a strategic character for an entire supply subsystem. The subsystem can effectively perform tasks related to the supply of a company, if it chooses a supplier or suppliers (a small number) that can meet the requirements, which are put in the supply subsystem and refer to the quality, quantity, price, delivery deadlines and other deadlines, reliability, flexibility, as well as other goals that need to be fulfilled satisfying other criteria, which are presented in the rest of the paper and which are determined by a literature review and research in the economic system. The search for suppliers that fulfil the previously written is a permanent and primary task. For this purpose it is necessary to continuously collect and process data on suppliers, establish and maintain adequate relations with them, and then to develop and apply methods for evaluation and ranking of potential suppliers.

The main aim of this paper is to make a decision on selecting the best supplier in company for production plastic bags and foils taking into account the uncertain-

*Corresponding author. E-mails: zeljko.stevic@sf.ues.rs.ba,zeljkostevic88@yahoo.com

\#Deputy Editor-in-Chief of the TRANSPORT - the manuscript was handled by one of the Associate Editors, who made all decisions related to the manuscript (including the choice of referees and the ultimate decision on the revision and publishing). 
ties and inaccuracies that emerge in such processes. Beside main aim, this paper has and several other aims. The first is to improve the methodology for treating uncertainties and subjectivity in the process of supplier selection. The second aim is to is to present an integrated Fuzzy multi-criteria model, integrated Fuzzy Analytic Hierarchy Process (Fuzzy AHP) and Fuzzy Evaluation based on Distance from Average Solution (Fuzzy EDAS) methods that responds to the need for production companies to evaluate potential suppliers and to respond to practical and realistic environmental conditions. The third aim of the paper is to motivate other authors toward use of this fuzzy integrated model, since the advantages of model that are emphasized in this paper are a one of logical motive for their wider application. In this multi-criteria model, making a decision on the most suitable supplier has a significant influence on the quality of supply chain since the choice of proper alternative provides easier and better functioning of companies.

The one of reason for the Fuzzy AHP method application it is ability to equally handle quantitative and qualitative criteria. Fuzzy AHP according to Hashemkhani Zolfani et al. (2012) was used for obtaining more decisive judgments by prioritizing the selection criteria and weighting them in the presence of vagueness in the problems. Triangular fuzzy numbers is used to extend the range of a crisp comparison matrix of the AHP method, because human assessment in the comparison of criteria and suppliers is really vague. According to Kahraman et al. (2003) though the purpose of AHP is to capture the expert's knowledge, the conventional AHP still cannot reflect the human thinking style. Therefore, Fuzzy AHP was developed to solve the hierarchical fuzzy problems. The most significant characteristics of the EDAS method are its simplicity and lower computational process. The main reason for applying the Fuzzy EDAS method is its great application so far since, according to Stević et al. (2017a), in a very short time, it has found its way through the wide application in solving engineering problems, as well as problems in business decision-making. Furthermore, one of the reasons for using EDAS method, according to Stević et al. (2017a), is a mathematical apparatus, which assumes the evaluation of alternatives on the basis of positive and negative deviations from the average solution. Such model presents very important support in decision-making in everyday conflict situations.

The paper is structured throughout several chapters. The chapter introduction briefly describes the importance, which suppliers have on the entire supply chain and company's performance. The 1st chapter provides a literature review consisting of two parts: a review of the criteria used in this field and a review of the most commonly used Multi-Criteria Decision-Making (MCDM) methods for evaluating and supplier selection. The 2 nd chapter provides basic information and steps of the Fuzzy AHP method, and basic settings of the Fuzzy EDAS method. The 3d chapter comprises the proposed model with steps, which are implemented in it described in detail. The chapter consists of evaluating the criteria for supplier selection in more than ten production areas and forming a smaller set of criteria for further calculation using the Fuzzy AHP method. After that, applying one of the recent MCDM methods, Fuzzy EDAS, a selection of suppliers is made in a company for the production of plastic bags and foils. In 4th chapter, a sensitivity analysis is performed, in which different sets with different values of criteria are defined, based on which the stability of the proposed model is checked. The last chapter provides a conclusion with the discussion of the results obtained and guidelines for future research.

\section{Literature review}

\subsection{Criteria for supplier selection}

The evaluation of suppliers is a constant process that requires taking into account a certain number of criteria on the basis of which it is necessary to make a decision on the selection of the most suitable suppliers. Various studies propose different criteria, and financial indicators, quality and delivery, are present in almost all studies as criteria for the selection of suppliers (Min, Galle 1999; Pi, Low 2006; Parthiban et al. 2012; Mehralian et al. 2012; Fallahpour et al. 2017). These criteria can be observed as the main criteria, which are further subdivided into sub-criteria if a larger number or criteria are considered or as criteria without sub-criteria.

Table 1 shows the criteria of the model proposed in this paper and an overview of the studies in which they have been used. Although qualitative criteria have been more and more applied, based on Table 1, it can be concluded that the quantitative criteria continue to be applied to a great extent. Material price, quality and delivery time are the most commonly used criteria in the considered studies. Out of a total of 34 papers, they are used as criteria in 27 (material price), 26 (quality) and 22 (delivery time). Financial stability is present in $59 \%$ of reviewed studies, logistics capacities in 53\%, while reputation and communication system criteria are used in approximately $40 \%$ of papers. The criteria that are most rarely used are volume discounts, awards and honours, reactions to reclamation and information technology.

\subsection{Methods for supplier selection}

According to Triantaphyllou and Mann (1995), MCDM plays an important role in real-life problems, as there are a large number of everyday decisions to be make which include a huge number of the criteria. According to Chen et al. (2015), MCDM is an effective, systemic and quantitative way of solving vital real-life problems with a large number of alternatives and several (opposing) criteria. The daily use of MCDM (Mardani et al. 2015; Karabašević et al. 2018; Badi et al. 2018; Pamučar et al. 2018; Božanić et al. 2018) has certainly contributed to the increasing popularity of this field (Zavadskas et al. 2014). Logistics systems are extremely important for the functioning of the complete supply chain, so almost every day the evaluation and selection of suppliers is carried out and according Stević et al. (2017a, 2017b) this is one of the most important steps in optimizing logistics systems. 
Table 1. Review of supplier criteria in literature - the proposed criteria in this study

\begin{tabular}{|c|c|c|}
\hline Criteria & Sub-criteria & Reference \\
\hline \multirow{5}{*}{ 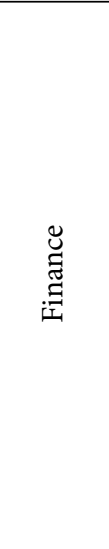 } & Price of material & $\begin{array}{l}\text { Fallahpour et al. (2017); Birgün Barla (2003); Chan, Kumar (2007); Dickson (1966); } \\
\text { Gencer, Gürpinar (2007); Hruška et al. (2014); Jamil et al. (2013); Kilic (2013); Lee (2009); } \\
\text { Muralidharan et al. (2002); Özbek (2015); Simpson et al. (2002); Stević et al. (2016); Tam, } \\
\text { Tummala (2001); Weber et al. (1991); Yücenur et al. (2011); Rezaei et al. (2014); Wang et al. } \\
\text { (2017); Büyüközkan, Göçer (2017) }\end{array}$ \\
\hline & Financial stability & $\begin{array}{l}\text { Birgün Barla (2003); Çebi, Bayraktar (2003); Chan, Kumar (2007); Dickson (1966); } \\
\text { Ellram (1990); Gencer, Gürpinar (2007); Hruška et al. (2014); Jamil et al. (2013); Lee (2009); } \\
\text { Muralidharan et al. (2002); Simpson et al. (2002); Rezaei et al. (2014); Büyüközkan, } \\
\text { Göçer (2017) }\end{array}$ \\
\hline & Method of payment & $\begin{array}{l}\text { Hruška et al. (2014); Hudymáčová et al. (2010); Baležentis, A., Baležentis, T. (2011); } \\
\text { Stević et al. (2016); Ting, Cho (2008); Lam et al. (2010) }\end{array}$ \\
\hline & Price of transport & $\begin{array}{l}\text { Chan, Kumar (2007); Hruška et al. (2014); Hudymáčová et al. (2010); Jamil et al. (2013); } \\
\text { Kahraman et al. (2003); Lee (2009); Ting, Cho (2008); Yücenur et al. (2011) }\end{array}$ \\
\hline & Volume discounts & Jamil et al. (2013); Wang (2010) \\
\hline \multirow{5}{*}{ 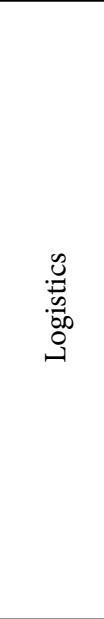 } & Delivery time & $\begin{array}{l}\text { Fallahpour et al. (2017); Chan, Kumar (2007); Dickson (1966); Gencer, Gürpinar (2007); } \\
\text { Hruška et al. (2014); Jamil et al. (2013); Kilic (2013); Lin, Chang (2008); Muralidharan et al. } \\
\text { (2002); Özbek (2015); Stević et al. (2016); Wang et al. (2004); Yücenur et al. (2011); } \\
\text { Wang et al. (2017); Büyüközkan, Göçer (2017) }\end{array}$ \\
\hline & Reliability & $\begin{array}{l}\text { Birgün Barla (2003); Çebi, Bayraktar (2003); Chan, Kumar (2007); Gencer, Gürpinar (2007); } \\
\text { Hudymáćová et al. (2010); Jamil et al. (2013); Lee (2009); Muralidharan et al. (2002); } \\
\text { Wang et al. (2004); Yücenur et al. (2011); Büyüközkan, Göçer (2017) }\end{array}$ \\
\hline & Flexibility & $\begin{array}{l}\text { Fallahpour et al. (2017); Çebi, Bayraktar (2003); Chan, Kumar (2007); Hudymáčová et al. } \\
\text { (2010); Jamil et al. (2013); Kannan, Tan (2006); Muralidharan et al. (2002); Uygun et al. } \\
\text { (2013); Wang et al. (2004); Yücenur et al. (2011); Rezaei et al. (2014); Wang et al. (2017) }\end{array}$ \\
\hline & Logistics capacity & $\begin{array}{l}\text { Fallahpour et al. (2017); Dickson (1966); Ellram (1990); Hruška et al. (2014); Jamil et al. } \\
\text { (2013); Kahraman et al. (2003); Kannan, Tan (2006); Lee (2009); Lin, Chang (2008); Simpson } \\
\text { et al. (2002); Tam, Tummala (2001); Uygun et al. (2013); Zeydan et al. (2011); Yücenur et al. } \\
\text { (2011); Rezaei et al. (2014) }\end{array}$ \\
\hline & $\begin{array}{l}\text { The percentage of correct } \\
\text { realization of delivery }\end{array}$ & Jamil et al. (2013); Ting, Cho (2008); Uygun et al. (2013); Wang et al. (2004) \\
\hline \multirow{5}{*}{ 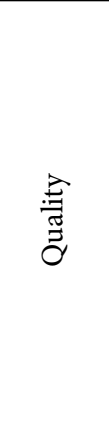 } & Quality of material & $\begin{array}{l}\text { Fallahpour et al. (2017); Chan, Kumar (2007); Dickson (1966); Gencer, Gürpinar (2007); } \\
\text { Hruška et al. (2014); Jamil et al. (2013); Kannan, Tan (2006); Kilic (2013); Lee (2009); } \\
\text { Muralidharan et al. (2002); Özbek (2015); Simpson et al. (2002); Baležentis, A., } \\
\text { Baležentis, T. (2011); Stević et al. (2016); Wang et al. (2017) }\end{array}$ \\
\hline & Warranty period & Dickson (1966); Simpson et al. (2002); Guo et al. (2009); Wang (2010) \\
\hline & Certification of products & $\begin{array}{l}\text { Birgün Barla (2003); Hudymáčová et al. (2010); Jamil et al. (2013); Simpson et al. (2002); } \\
\text { Ting, Cho (2008); Uygun et al. (2013) }\end{array}$ \\
\hline & Reputation & $\begin{array}{l}\text { Çebi, Bayraktar (2003); Chan, Kumar (2007); Dickson (1966); Ellram (1990); Kilic (2013); } \\
\text { Lee (2009); Lin, Chang (2008); Özbek (2015); Tam, Tummala (2001); Weber et al. (1991); } \\
\text { Yücenur et al. (2011); Rezaei et al. (2014); Wang et al. (2017) }\end{array}$ \\
\hline & Awards and honors & Jamil et al. (2013) \\
\hline \multirow{5}{*}{ 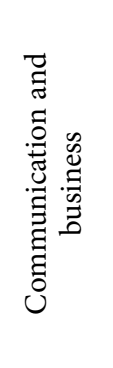 } & Communication system & $\begin{array}{l}\text { Çebi, Bayraktar (2003); Chan, Kumar (2007); Dickson (1966); Kahraman et al. (2003); } \\
\text { Lee (2009); Lin, Chang (2008); Özbek (2015); Simpson et al. (2002); Uygun et al. (2013); } \\
\text { Guo et al. (2009); Yücenur et al. (2011); Rezaei et al. (2014) }\end{array}$ \\
\hline & $\begin{array}{l}\text { Speed of response to } \\
\text { requirements }\end{array}$ & $\begin{array}{l}\text { Jamil et al. (2013); Kahraman et al. (2003); Özbek (2015); Tam, Tummala (2001); Ting, } \\
\text { Cho (2008); Uygun et al. (2013); Wang et al. (2004); Büyüközkan, Göçer (2017) }\end{array}$ \\
\hline & Reactions to reclamation & Özbek (2015); Ting, Cho (2008); Zeydan et al. (2011) \\
\hline & Information Technology & Jamil et al. (2013) \\
\hline & Clean of business & $\begin{array}{l}\text { Jamil et al. (2013); Lee (2009); Zeydan et al. (2011); Guo et al. (2009); Yücenur et al. (2011); } \\
\text { Wang et al. (2017) }\end{array}$ \\
\hline
\end{tabular}

There are a number of methods that belong to the field of MCDM, and most often used, at least when it refers to the selection of suppliers, is the AHP method, as it can be seen in Table 2, where a review of the most frequently used MCDM methods in the field of evaluation and supplier selection is given. The AHP method has been used to solve a problem of the selection of suppliers, either in conventional form or in combination with fuzzy logic (Chen et al. 2006; Kabi et al. 2017), while Ho, along with co-authors - in Ho et al. (2010) conducted a literature review of the application of MCDM methods in the mentioned field. Keshavarz Ghorabaee et al. (2017b) conducted a literature 
review of the application of MCDM methods in fuzzy environments. The AHP is often used in combination with other methods where the authors use the AHP to estimate the weight of criteria, and the other methods for obtaining the final rank of alternatives. Combination of the Fuzzy AHP and Technique for Order of Preference by Similarity to Ideal Solution (TOPSIS) methods (Ball, Korukoğlu 2009; Mahmoodzadeh et al. 2007) the combination of the Fuzzy AHP and Fuzzy TOPSIS (Sun 2010; Jain et al. 2018).

\section{Material and methods}

\subsection{Fuzzy sets}

Fuzzy sets are sets whose elements have degrees of membership. The theory of fuzzy sets was first introduced by Zadeh (1965), whose application enables decision makers to effectively deal with the uncertainties. Fuzzy sets used generally Triangular Fuzzy Number (TFN), trapezoidal and Gaussian fuzzy numbers, which convert uncertain fuzzy numbers. The operational laws of TFN $\tilde{A}_{1}=\left(l_{1}, m_{1}, u_{1}\right)$ and $\tilde{A}_{2}=\left(l_{2}, m_{2}, u_{2}\right)$ and can find in Turskis et al. (2015). Some of the definitions related to fuzzy sets and fuzzy numbers, which are used to Fuzzy EDAS method can find in Keshavarz Ghorabaee et al. (2016).

\subsection{Fuzzy AHP method}

TFN, that were used in this research are marked as $\left(l_{1}, m_{1}, u_{1}\right)$ where $l_{i j}$ is the smallest possible value, $m_{i j}$ is the value most nearest of crisp and $u_{i j}$ is highest value. In this research, the AHP method by Chang (1996), is adopted. Chang's expanded analysis includes four steps.

Step 1 . The value of fuzzy synthetic extent $S_{i}$ with respect to the $i$-th criteria is defined as:

$$
S_{i}=\sum_{j=1}^{n} M_{g i}^{j}\left(\sum_{i=1}^{n} \sum_{i=1}^{m} M_{g i}^{j}\right)^{-1} .
$$

Step 2. The degree of possibility of $S_{b} \geq S_{a}$ is defined as:

$$
V\left(S_{b} \geq S_{a}\right)=\left\{\begin{array}{l}
1, \text { if } m_{b} \geq m_{a} ; \\
0, \text { if } l_{a} \geq u_{b} ; \\
\frac{l_{a}-u_{b}}{\left(m_{b}-u_{b}\right)-\left(m_{a}-l_{a}\right)}, \text { otherwise. }
\end{array}\right.
$$

Step 3. Level of possibility for convex fuzzy number to be greater than $k$ convex number $S_{i}(i=1,2, \ldots, k)$ can be defined as follows:

\begin{tabular}{|c|c|c|}
\hline Reference & Field of application & Method \\
\hline Kahraman et al. (2003) & A white goods production companies & Fuzzy AHP \\
\hline Zeydan et al. (2011) & Automotive industry & $\begin{array}{l}\text { Fuzzy AHP, Fuzzy TOPSIS, Data Envelopment } \\
\text { Analysis (DEA) }\end{array}$ \\
\hline Lee (2009) & Production TFT-LCD & Fuzzy AHP \\
\hline Asamoah et al. (2012) & Pharmaceutical industry & AHP \\
\hline Khorasani, Bafruei (2011) & Pharmaceutical industry & Fuzzy AHP \\
\hline Hruška et al. (2014) & Company of production in Czech & AHP \\
\hline Tam, Tummala (2001) & Telecommunication company & AHP \\
\hline Parthiban et al. (2012) & Automotive industry & AHP \\
\hline Lima Junior et al. (2014) & Automotive industry & Fuzzy AHP, Fuzzy TOPSIS \\
\hline Rezai et al. (2014) & Airline industry & Fuzzy AHP \\
\hline Chamodrakas et al. (2010) & Electronic industry & Fuzzy AHP \\
\hline Kilincci, Onal (2011) & A white goods production company & Fuzzy AHP \\
\hline Jamil et al. (2013) & Automotive industry & AHP, Fuzzy AHP, TOPSIS, Fuzzy TOPSIS \\
\hline Hudymáčová et al. (2010) & Production of machine parts & AHP \\
\hline Keshavarz Ghorabaee et al. (2016) & Detergent manufacturer & Fuzzy EDAS \\
\hline Bronja, Harun, Bronja, Haris (2015) & Production of exhaust systems of cars & Fuzzy AHP, Fuzzy TOPSIS \\
\hline Eraslan, Atalay (2014) & $\begin{array}{l}\text { A company for the production of } \\
\text { electronic cards }\end{array}$ & Fuzzy AHP, Fuzzy TOPSIS \\
\hline Chiouy et al. (2011) & Electronic industry & Fuzzy AHP \\
\hline Hashemian et al. (2014) & Dairy industry & $\begin{array}{l}\text { Fuzzy AHP, Fuzzy Preference Ranking Organization } \\
\text { METHod for Enrichment of Evaluations } \\
\text { (Fuzzy PROMETHEE) }\end{array}$ \\
\hline Liao et al. (2016) & Watch firm & $\begin{array}{l}\text { Fuzzy AHP, Fuzzy Additive Ratio ASsessment } \\
\text { (ARAS-F), Multi Segment Goal Programming } \\
\text { (MSGP) }\end{array}$ \\
\hline Saad et al. (2016) & Automotive industry & AHP, Fuzzy AHP \\
\hline Stević et al. (2017a) & Construction company & $\begin{array}{l}\text { Rough DEcision-MAking Trial and Evaluation } \\
\text { Laboratory (Rough DEMATEL), Rough EDAS }\end{array}$ \\
\hline
\end{tabular}

Table 2. Review of methods for the evaluation and supplier selection 


$$
\begin{aligned}
& V\left(S_{i} \geq S_{1}, S_{2}, \ldots, S_{k}\right)=\min V\left(S_{i} \geq S_{k}\right)=w^{\prime}\left(S_{i}\right) ; \\
& d^{\prime}\left(A_{i}\right)=\min V\left(S_{i} \geq S_{k}\right), k \neq i, k=1,2, \ldots, n .
\end{aligned}
$$

The weight vector is given by the following expression:

$$
W^{\prime}=\left(d^{\prime}\left(A_{1}\right), d^{\prime}\left(A_{2}\right), \ldots, d^{\prime}\left(A_{n}\right)\right)^{T} \text {. }
$$

Step 4. Through normalization, the weight vector is reduced to the phrase:

$$
W=\left(d\left(A_{1}\right), d\left(A_{2}\right), \ldots, d\left(A_{n}\right)\right)^{T} .
$$

\subsection{Fuzzy EDAS method}

The Evaluation based on Distance from Average Solution EDAS method was developed by Keshavarz Ghorabaee et al. (2015) for multi-criteria inventory classification. In Fuzzy EDAS method the decision-makers express the weights of criteria and the rating of alter-natives with respect to each criterion by linguistic terms. These linguistic terms are quantified by positive trapezoidal fuzzy numbers. The steps of the extended Fuzzy EDAS method are presented as follows (Keshavarz Ghorabaee et al. 2016).

Step 1. Construct the average decision matrix $X$, shown as follows:

$$
\begin{aligned}
& X=\left[\tilde{x}_{i j}\right]_{n x m} ; \\
& \tilde{x}_{i j}=\frac{1}{k} \oplus_{p=1}^{k} \tilde{x}_{i j}^{p},
\end{aligned}
$$

where: $\tilde{x}_{i j}^{p}$ denotes the performance value of alter-native $A_{i}(1 \leq i \leq n)$ with respect to criterion $c_{j}(1 \leq j \leq m)$ assigned by the $p$-th decision-maker $(1 \leq p \leq k)$.

Step 2. Construct the matrix of criteria weights, shown as follows:

$$
\begin{aligned}
& W=\left[\tilde{w}_{j}\right]_{1 x m} ; \\
& \tilde{w}_{j}=\frac{1}{k} \oplus_{p=1}^{k} \tilde{w}_{j}^{p},
\end{aligned}
$$

where: $\tilde{w}_{j}^{p}$ denotes the weight of criterion $c_{j}(1 \leq j \leq m)$ assigned by the $p$-th decision-maker $(1 \leq p \leq k)$.

Step 3. Construct the matrix of average solutions, shown as follows:

$$
\begin{aligned}
& A V=\left[\widetilde{a v_{j}}\right]_{1 x m} ; \\
& \widetilde{a v} j=\frac{1}{n} \oplus_{i=1}^{n} \tilde{x}_{i j} .
\end{aligned}
$$

The elements of this matrix $a v_{j}$ represents the average solutions with respect to each criterion.

Step 4. Suppose that B is the set of benefit criteria and $\mathrm{N}$ is the set of non-benefit criteria. In this step the matrices of positive distance from average (PDA) and negative distance from average (NDA) are calculated according to the type of criteria (benefit and non-benefit), shown as follows:

$$
P D A=\left[\widetilde{p d a} a_{i j}\right]_{n x m} ;
$$

$$
\begin{aligned}
& N D A=\left[\widetilde{n d a}_{i j}\right]_{n x m} ; \\
& \widetilde{p d a}_{i j}=\left\{\begin{array}{l}
\frac{\psi\left(\tilde{x}_{i j}-\widetilde{a v}_{j}\right)}{k\left(\widetilde{a v}_{j}\right)}, \text { if } j \in B ; \\
\frac{\psi\left(\widetilde{a v_{j}}-\tilde{x}_{i j}\right)}{k\left(\widetilde{a v_{j}}\right)}, \text { if } j \in N ;
\end{array}\right. \\
& \widetilde{n d a}_{i j}=\left\{\begin{array}{l}
\frac{\psi\left(\widetilde{a v_{j}}-\tilde{x}_{i j}\right)}{k\left(\widetilde{a v_{j}}\right)}, \text { if } j \in B ; \\
\frac{\psi\left(\tilde{x}_{i j}-\widetilde{a v}_{j}\right)}{k\left(\widetilde{a v}_{j}\right)}, \text { if } j \in N,
\end{array}\right.
\end{aligned}
$$

where: $\widetilde{p d a}_{i j}$ and $\widetilde{n d a} a_{i j}$ denote the positive and negative distance of performance value of $i$-th alternative from the average solution in terms of $j$-th criterion, respectively.

Step 5. Calculate the weighted sum of positive and negative distances for all alternatives, shown as follows:

$$
\begin{aligned}
& \widetilde{s p}_{i}=\oplus_{i=1}^{m}\left(\tilde{w}_{j} \otimes \widetilde{p d a_{i j}}\right) ; \\
& \widetilde{s n_{i}}=\oplus_{i=1}^{m}\left(\tilde{w}_{j} \otimes \widetilde{n d a} i j\right) .
\end{aligned}
$$

Step 6. The normalize values of e $s p_{i}$ and $s n_{i}$ for all alternatives are calculated as follows:

$$
\begin{aligned}
& {\widetilde{n s p_{i}}}_{i}=\frac{{\widetilde{s p_{i}}}_{\max _{i}\left(k\left(\widetilde{s p}_{i}\right)\right)}}{\widetilde{s n}_{i}} . \\
& \widetilde{n s n_{i}}=1-\frac{\max _{i}\left(k\left(\widetilde{s n_{i}}\right)\right)}{} .
\end{aligned}
$$

Step 7. Calculate the appraisal score $(\widetilde{a s})$ for all alternatives, shown as follows:

$$
\widetilde{a s}_{i}=\frac{1}{2}\left(\widetilde{n s p_{i}} \otimes \widetilde{n s n_{i}}\right) \text {. }
$$

Step 8. Rank the alternatives according to the decreasing values of appraisal scores $\widetilde{a s}_{i}$. In other words, the alternative with the highest appraisal score is the best choice among the candidate alternatives.

\section{Proposed model}

The first stage in solving decision-making tasks is highquality data collection and their preparation, which can greatly affect the final result. Figure 1 shows the model proposed in this research, which consists of four stages that comprise a total of 14 steps and a large number of sub-steps.

\subsection{First stage - data collection and preparation}

The first stage of the proposed model consists of four steps. The first one is the formation of a set of twenty criteria based on a literature review, which is presented in 


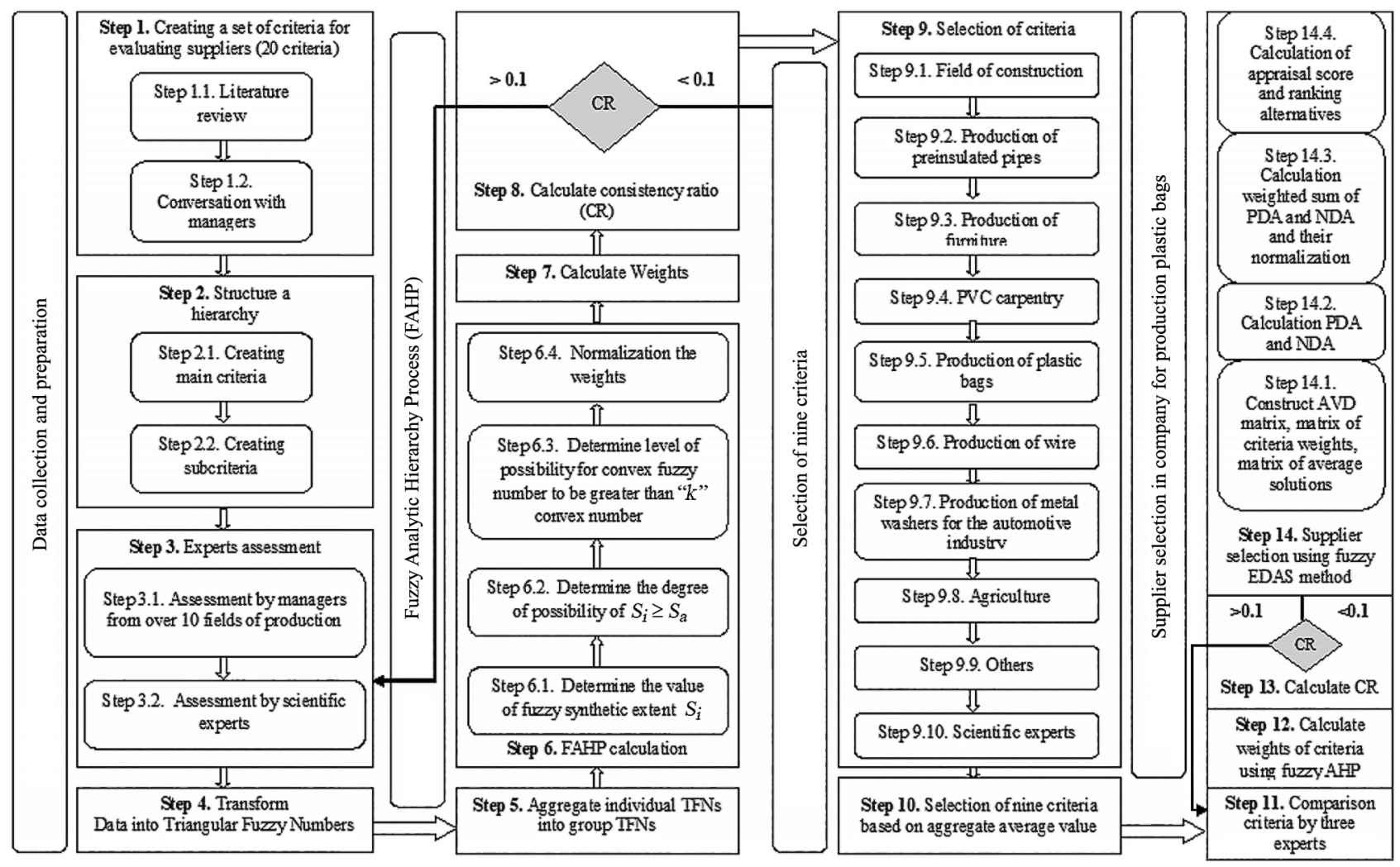

Figure 1. The proposed model for supplier selection

detail in the first chapter (literature review), and an additional sub-step that implies the opinion of managers from production areas. After that, the second step involves the formation of a structure that consists of the main criteria: finance, logistics, quality, communications and business operations. Each of these four criteria is further divided into five sub-criteria as shown in Table 1, and each of them is explained in detail in the rest of paper at stage two. The step three of the first stage consists of two substeps, which include the evaluation of all criteria by managers in more than 10 different production activities by linguistic variables. In addition, it takes into account the opinions of leading scientists who have been dealing with problems in a supply chain sector for many years and have a huge experience that can contribute to this model. Subsequently, the final step of this stage is the transformation of data presented by linguistic variables into triangular fuzzy numbers.

\subsection{Second stage - application of Fuzzy AHP}

The first step of the second stage, i.e., the fifth step of the model, involves the aggregation of experts' individual responses presented by triangular fuzzy numbers into group TFNs obtained by applying the geometric mean. The sixth step involves the application of the Fuzzy AHP method, and the sub-steps are the steps of the Fuzzy AHP method. The seventh step includes the calculation of the weight values of the criteria. In order to access the next eighth step of the model, it is necessary to perform defuzzifica- tion of the values from step five. Then applying the steps of the classic AHP method, a consistency check of the obtained values is performed, i.e., a degree of Consistency Ratio (CR) is calculated. If the CR is in the allowed range, the next step, i.e., the next stage is approached. If that is not the case, the supplier evaluation questionnaire should be returned to the managers for re-filling. In that case, it is necessary to return to step three and, after re-evaluating the criteria, to repeat all further steps. In the following part, it is provided an example of applying the Fuzzy AHP method in a company for the production of plastic bags and foils, and, before that, the explanation of all criteria that are a part of the model.

As it can be seen in the first chapter, there are a large number of criteria used to evaluate and select suppliers. However, in some cases, especially when it refers to using certain conflicting criteria, a smaller number is a better solution. Therefore, in the rest of the paper, the proposed model of twenty criteria shown in Table 1 is reduced to nine using the knowledge of managers in production companies, as well as strict requirements, which the market place sets before them. In the rest of the paper, there is an example of calculating the values of criteria and identifying nine, the most important ones in a company for the production of plastic bags and foil for the reasons that in this paper the verification of the supplier selection model has been presented in the afore mentioned company.

Fuzzy important weight of the criteria is calculated by taking geometric mean of the responses of the managers this is shown in Table 3. 
Table 3. Fuzzy important weight calculated by taking geometric mean

\begin{tabular}{|c|c|c|c|c|c|c|c|c|c|c|c|c|}
\hline & \multicolumn{3}{|c|}{$C_{1}$} & \multicolumn{3}{|c|}{$C_{2}$} & \multicolumn{3}{|c|}{$C_{3}$} & \multicolumn{3}{|c|}{$C_{4}$} \\
\hline$C_{1}$ & 1.00 & 1.00 & 1.00 & 0.79 & 1.14 & 1.44 & 0.67 & 1.00 & 2.00 & 1.14 & 1.65 & 2.15 \\
\hline$C_{2}$ & 0.69 & 0.87 & 1.26 & 1.00 & 1.00 & 1.00 & 0.51 & 0.69 & 1.10 & 0.63 & 1.14 & 1.65 \\
\hline$C_{3}$ & 0.50 & 1.00 & 1.50 & 0.91 & 1.44 & 1.96 & 1.00 & 1.00 & 1.00 & 1.65 & 2.15 & 2.66 \\
\hline$C_{4}$ & $\begin{array}{l}0.46 \\
\end{array}$ & 0.61 & 0.87 & 0.61 & 0.87 & 1.59 & 0.38 & 0.46 & 0.61 & 1.00 & 1.00 & 1.00 \\
\hline
\end{tabular}

To determine fuzzy combination expansion for each one of the criteria, first we calculate $\sum_{j=1}^{n} M_{g i}^{j}$ value for each
row of the matrix.

$C_{1}=(1+0.794+0.667+1.145$

$1+1.145+1.000+1.651$

$1+1.442+2.000+2.154)=$

$(3.605 ; 4.796 ; 6.597)$, etc.

The $\sum_{i=1}^{n} \sum_{j=1}^{n} M_{g i}^{j}$ value is calculated as:

$(3.605 ; 4.796 ; 6.597)+$

$(2.834 ; 3.172 ; 5.012)+$

$(4.060 ; 5.597 ; 7.114)+$

$(2.446 ; 2.943 ; 4.067)=$

$(12.945 ; 17.047 ; 22.789)$.

Then, $S_{i}=\sum_{j=1}^{n} M_{g i}^{j}\left(\sum_{i=1}^{n} \sum_{j=1}^{m} M_{g i}^{j}\right)^{-1}$ :

$S_{1}=(3.605 ; 4.796 ; 6.597) \times$

$(1 / 22.789 ; 1 / 17.047 ; 1 / 12.945)=$

$(0.158 ; 0.281 ; 0.510)$, etc.

In Table 4 is shown values obtained after first step.

Table 4. Values obtained after first step

\begin{tabular}{|c|c|c|c|c|c|c|}
\cline { 2 - 7 } \multicolumn{1}{c|}{} & & $m$ & $u$ & $\frac{1}{\sum_{i=1}^{n} u_{i}}$ & $\frac{1}{\sum_{i=1}^{n} m_{i}}$ & $\frac{1}{\sum_{i=1}^{n} l_{i}}$ \\
\hline$C_{1}$ & 3.605 & 4.796 & 6.597 & 0.158 & 0.281 & 0.510 \\
\hline$C_{2}$ & 2.834 & 3.712 & 5.012 & 0.124 & 0.218 & 0.387 \\
\hline$C_{3}$ & 4.060 & 5.597 & 7.114 & 0.178 & 0.328 & 0.550 \\
\hline$C_{4}$ & 2.446 & 2.943 & 4.067 & 0.107 & 0.173 & 0.314 \\
\hline$\Sigma$ & 12.945 & 17.047 & 22.789 & \multicolumn{3}{|r}{} \\
\cline { 1 - 5 } & & &
\end{tabular}

Now, the $V$ values (preference order) are calculated using second step:

$V\left(S_{1} \geq S_{2}\right)=1 ;$

$V\left(S_{1} \geq S_{3}\right)=\frac{0.178-0.510}{(0.281-0.510)-(0.328-0.178)}=0.876$;

$V\left(S_{1} \geq S_{4}\right)=1$.

The priorities of weights are calculated using:

$d^{\prime}=\left(C_{1}\right) \min (1 ; 0.876 ; 1)=0.876$;

$d^{\prime}=\left(C_{2}\right) \min (0.783 ; 0.654 ; 1)=0.654$;

$$
\begin{aligned}
& d^{\prime}=\left(C_{3}\right) \min (1 ; 1 ; 1)=1 ; \\
& d^{\prime}=\left(C_{4}\right) \min (0.589 ; 0.808 ; 0.466)=0.466
\end{aligned}
$$

After the four step is applied, weight values are obtained, and normalized weights of criteria are received:

$$
\begin{aligned}
& W^{\prime}=(0.876 ; 0.654 ; 1 ; 0.466) ; \\
& W=(0.292 ; 0.218 ; 0.334 ; 0.156) .
\end{aligned}
$$

Obtained weights of criteria indicate that the third criterion (quality) is most important, while second most important criteria is finance. Logistics has lower value of finance, while the fourth criterion of communication and business has a minimum value.

After the calculated weights of criteria, it is necessary to check the consistency. It is necessary to perform defuzzification of values by using the following equation (Kwong, Bai 2003):

$$
M_{-c r i s p}=\frac{(4 \cdot m+l+u)}{6} .
$$

After defuzzification shown in the previous table, by applying the steps of conventional AHP method, we obtain the following values Table $5: \lambda_{\max }=4.105 ; C I=0.035$; $C R=0.039$, which means that the CR is 0.039 , which is much less than the maximum permitted limit of 0.08 for this matrix size.

Table 5 shows all local and global values of all criteria, their local and global ranking, and calculated CR for all comparisons made. The criteria indicated in the table are the criteria selected for the company for the production of plastic bags and foils. All calculated CRs are within allowed limits, which means that in the decision-making process subjectivity is very small, which is essentially the goal.

\subsection{Third stage - selection of nine criteria}

In the same way as shown at the previous stage, using the described methodology in more than ten different production areas, ranking of the criteria and selection of the most important nine ones have been completed, which are used further in the paper. Table 6 shows the final results for all areas given at the bottom of the table. The results presented include local and global ranking as well as aggregated aver-age ranking values. Figure 2 selects the criteria according to aggregated average values, which represents the tenth step of the third stage. After describing the methodology and applying the Fuzzy AHP method for determining the significance of criteria, a set of nine criteria has been identified, which are further applied to the 
Table 5. Weights of criteria and sub-criteria in company for production plastic bags and foil

\begin{tabular}{|c|c|c|c|c|c|c|c|c|c|c|}
\hline & Criteria & $w_{j}$ & CR & & Sub-criteria & $\begin{array}{c}\text { Local } \\
\text { weights }\end{array}$ & $\begin{array}{l}\text { Global } \\
\text { weights }\end{array}$ & $\begin{array}{c}\text { Local } \\
\text { rank }\end{array}$ & $\begin{array}{c}\text { Global } \\
\text { rank }\end{array}$ & $\mathrm{CR}$ \\
\hline \multirow{5}{*}{1.} & \multirow{5}{*}{ Finance } & \multirow{5}{*}{0.292} & \multirow{20}{*}{0.039} & 1.1 & Price of material & 0.297 & 0.087 & 1 & 2 & \multirow{5}{*}{0.026} \\
\hline & & & & 1.2 & Financial stability & 0.206 & 0.060 & 3 & 5 & \\
\hline & & & & 1.3 & Method of payment & 0.117 & 0.034 & 5 & 13 & \\
\hline & & & & 1.4 & Price of transport & 0.119 & 0.035 & 4 & 12 & \\
\hline & & & & 1.5 & Volume discounts & 0.261 & 0.076 & 2 & 3 & \\
\hline \multirow{5}{*}{2.} & \multirow{5}{*}{ Logistics } & \multirow{5}{*}{0.218} & & 2.1 & Delivery time & 0.229 & 0.050 & 1 & 6 & \multirow{5}{*}{0.028} \\
\hline & & & & 2.2 & Reliability & 0.203 & 0.044 & 2 & 7 & \\
\hline & & & & 2.3 & Flexibility & 0.194 & 0.042 & 3 & 8 & \\
\hline & & & & 2.4 & Logistics capacity & 0.183 & 0.040 & 4 & 9 & \\
\hline & & & & 2.5 & $\begin{array}{l}\text { The percentage of correct } \\
\text { realization of delivery }\end{array}$ & 0.192 & 0.042 & 3 & 8 & \\
\hline \multirow{5}{*}{3.} & \multirow{5}{*}{ Quality } & \multirow{5}{*}{0.334} & & 3.1 & Quality of material & 0.354 & 0.118 & 1 & 1 & \multirow{5}{*}{0.023} \\
\hline & & & & 3.2 & Warranty period & 0.179 & 0.060 & 3 & 5 & \\
\hline & & & & 3.3 & Certification of products & 0.207 & 0.069 & 2 & 4 & \\
\hline & & & & 3.4 & Reputation & 0.206 & 0.069 & 2 & 4 & \\
\hline & & & & 3.5 & Awards and honours & 0.054 & 0.018 & 4 & 17 & \\
\hline \multirow{5}{*}{4.} & \multirow{5}{*}{$\begin{array}{l}\text { Communication } \\
\text { and business }\end{array}$} & \multirow{5}{*}{0.156} & & 4.1 & Communication system & 0.149 & 0.023 & 4 & 16 & \multirow{5}{*}{0.033} \\
\hline & & & & 4.2 & $\begin{array}{l}\text { Speed of response to } \\
\text { requirements }\end{array}$ & 0.196 & 0.031 & 3 & 14 & \\
\hline & & & & 4.3 & Reactions to reclamation & 0.238 & 0.037 & 2 & 11 & \\
\hline & & & & 4.4 & Information Technology & 0.172 & 0.027 & 5 & 15 & \\
\hline & & & & 4.5 & Clean of business & 0.246 & 0.038 & 1 & 12 & \\
\hline
\end{tabular}

Table 6. Final results of ranking criteria in over ten area of production

\begin{tabular}{|c|c|c|c|c|c|c|c|c|c|c|c|c|c|c|c|c|c|c|c|c|c|c|}
\hline & \multicolumn{2}{|c|}{$A$} & \multicolumn{2}{|c|}{ B } & \multicolumn{2}{|c|}{$\mathrm{C}$} & \multicolumn{2}{|c|}{$\mathrm{D}$} & \multicolumn{2}{|c|}{$\mathrm{E}$} & \multicolumn{2}{|c|}{$\mathrm{F}$} & \multicolumn{2}{|c|}{8} & \multicolumn{2}{|c|}{$\mathrm{H}$} & \multicolumn{2}{|c|}{$T$} & & \multicolumn{2}{|c|}{$\mathrm{AV}$} \\
\hline & LR & GR & $\mathrm{R}$ & GR & LR & GR & LR & GR & LR & GR & LR & GR & LR & GR & LR & GR & LR & GR & LR & GR & LR & GR \\
\hline$C_{1}$ & 3 & 4 & 2 & 5 & 1 & 1 & 3 & 8 & 1 & 2 & 2 & 3 & 2 & 4 & 3 & 6 & 2 & 2 & 1 & 7 & 1.83 & 3.56 \\
\hline$C_{2}$ & 4 & 12 & 4 & 15 & 2 & 3 & 1 & 3 & 3 & 5 & 3 & 7 & 3 & 6 & 4 & 7 & 3 & 7 & 2 & 10 & 2.70 & 7.41 \\
\hline$C_{3}$ & 1 & 2 & 1 & 3 & 3 & 10 & 4 & 11 & 5 & 13 & 1 & 1 & 4 & 13 & 2 & 5 & 4 & 9 & 3 & 11 & 2.38 & 5.95 \\
\hline$C_{4}$ & 5 & 14 & 5 & 17 & 5 & 14 & 5 & 14 & 4 & 12 & 4 & 11 & 5 & 18 & 5 & 14 & 5 & 14 & 5 & 17 & 4.78 & 14.35 \\
\hline$C_{5}$ & 2 & 3 & 3 & 8 & 3 & 10 & 2 & 5 & 2 & 3 & 5 & 15 & 1 & 3 & 1 & 4 & 1 & 1 & 4 & 16 & 2.07 & 5.03 \\
\hline$C_{6}$ & 2 & 8 & 1 & 2 & 1 & 4 & 2 & 6 & 1 & 6 & 1 & 4 & 1 & 5 & 3 & 11 & 1 & 3 & 1 & 2 & 1.28 & 4.45 \\
\hline$C_{7}$ & 1 & 7 & 2 & 7 & 3 & 8 & 1 & 3 & 2 & 7 & 3 & 8 & 4 & 11 & 4 & 12 & 2 & 4 & 2 & 3 & 2.17 & 6.34 \\
\hline$C_{8}$ & 3 & 9 & 4 & 12 & 4 & 12 & 2 & 6 & 3 & 8 & 4 & 9 & 5 & 12 & 1 & 9 & 4 & 10 & 3 & 8 & 3.05 & 9.30 \\
\hline$C_{9}$ & 5 & 13 & 3 & 10 & 5 & 14 & 3 & 9 & 4 & 9 & 2 & 7 & 2 & 7 & 2 & 10 & 5 & 12 & 5 & 12 & 3.35 & 10.04 \\
\hline$C_{10}$ & 4 & 11 & 5 & 13 & 2 & 6 & 4 & 12 & 3 & 8 & 5 & 12 & 3 & 10 & 5 & 13 & 3 & 7 & 4 & 9 & 3.66 & 9.79 \\
\hline$C_{11}$ & 1 & 1 & 1 & 1 & 1 & 2 & 1 & 1 & 1 & 1 & 1 & 2 & 1 & 1 & 3 & 3 & 1 & 1 & 1 & 1 & 1.12 & 1.28 \\
\hline$C_{12}$ & 2 & 7 & 4 & 9 & 4 & 7 & 3 & 4 & 3 & 5 & 3 & 6 & 3 & 14 & 4 & 7 & 2 & 4 & 3 & 5 & 3.02 & 6.33 \\
\hline$C_{13}$ & 4 & 10 & 2 & 4 & 3 & 5 & 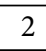 & 2 & 2 & 4 & 2 & 5 & 2 & $?$ & 2 & 2 & 3 & 5 & 2 & 4 & 2.32 & 3.81 \\
\hline$C_{14}$ & 3 & 8 & 3 & 6 & 2 & 3 & 4 & 6 & 2 & 4 & 4 & 12 & 4 & 15 & 1 & 1 & 3 & 5 & 4 & 6 & 2.78 & 5.33 \\
\hline$C_{15}$ & 5 & 16 & 5 & 19 & 5 & 16 & 5 & 16 & 4 & 17 & 5 & 16 & 5 & 19 & 5 & 8 & 4 & 15 & 5 & 18 & 4.78 & 15.63 \\
\hline$C_{16}$ & 5 & 15 & 5 & 18 & 5 & 15 & 4 & 13 & 4 & 16 & 4 & 14 & 4 & 16 & 4 & 18 & 4 & 13 & 4 & 17 & 4.28 & 15.40 \\
\hline$C_{17}$ & 2 & 6 & 1 & 11 & 4 & 13 & 3 & 12 & 3 & 14 & 1 & 6 & 1 & 8 & 3 & 17 & 1 & 6 & 2 & 14 & 1.83 & 9.99 \\
\hline$C_{18}$ & 3 & 7 & 2 & 12 & 2 & 11 & 2 & 10 & 2 & 11 & 2 & 10 & 2 & 9 & 1 & 15 & 2 & 8 & 1 & 13 & 1.81 & 10.36 \\
\hline$C_{19}$ & 4 & 14 & 3 & 14 & 3 & 12 & 5 & 15 & 5 & 15 & 4 & 14 & 3 & 11 & 2 & 16 & 3 & 11 & 4 & 17 & 3.48 & 13.76 \\
\hline$C_{20}$ & 1 & 5 & 4 & 16 & 1 & 10 & 1 & 7 & 1 & 12 & 3 & 13 & 5 & 17 & 2 & 16 & 3 & 11 & 3 & 15 & 2.01 & 11.46 \\
\hline
\end{tabular}

Notes: A - construction; B - production of the preinsulated pipes; C - production of furniture; D - PVC carpentry; E - production of plastic bags; F - production of wire; $\mathrm{G}$ - production of metal washers for the automotive industry; $\mathrm{H}$ - agriculture, I - others; J scientific experts. 
selection of suppliers in the company for the production of plastic bags and foils. The red line (Figure 2) denotes the division of criteria considered in the current course of research and those applied in its further part; since it is ranking of criteria, this means that the lowest value is the best solution (ranking within one production activity is based on the maximum value).

In relation to Table 6 where the criteria have been selected in the company that is the subject of the research in this paper and in relation to the selected criteria based on the evaluation of managers from all production activities, it can be concluded that there are not too many differences. Generally, the only difference is that, in the overall ranking of criteria, financial stability, which according to Table 7 is in the fifth position, is not in the first nine ones, so it is not considered in the rest of the model.

\subsection{Supplier selection in company for production plastic bags}

Integrated Fuzzy AHP - Fuzzy EDAS model was applied in company for production plastic bags and foils that is located in Bosnia and Herzegovina. The Fuzzy AHP method has been used to determine the significance of the criteria, and the Fuzzy EDAS to evaluate and select suppliers. The fourth stage of the model consists of four steps. Since there is a difference between the selected criteria and the most important criteria in the company, it is necessary to re-evaluate the criteria in step 11 . In step 12, a calculation of the values of criteria has been performed using the Fuzzy AHP method, in step 13, the CR test, and in the final step 14, the application of the Fuzzy EDAS method for supplier selection.

\subsection{Determination of criteria weights using Fuzzy AHP method}

After reevaluating, the process of obtaining weight values is identical to that described in detail in the second stage of the model, so results are: the weight values of the criteria are as follows: $C_{1}=0.177 ; C_{2}=0.166 ; C_{3}=0.106$;
$C_{4}=0.109 ; C_{5}=0.099 ; C_{6}=0.142 ; C_{7}=0.100 ; C_{8}=0.088 ;$ $C_{9}=0.013$, which means that the first criterion, the material quality, is the most significant. A little less important are material price and an additional volume discount criteria. Observing the obtained values in relation to the previous evaluation of the criteria in the company, it can be noticed that the results are approximate, which confirms the consistency of the managers of the company and their undisputed knowledge and experience. The subjectivity in evaluating the criteria is insignificant, which is confirmed by the following values: $\lambda_{\max }=9.311 ; C I=0.039$ and $C R=$ 0.027 .

\subsection{Supplier selection using Fuzzy EDAS method}

To select suppliers, it is used one of the newer MCDM methods, i.e., the fuzzy EDAS method, developed in 2016, while its conventional form was developed one year earlier. Several papers have already been published in various fields that apply this method either in its conventional or other forms (Turskis, Juodagalviene 2016; Kahraman et al. 2017; Keshavarz Ghorabaee et al. 2017a, 2017c, 2018a, 2018b; Stević et al. 2017a; 2018a; Ecer 2018; Zavadskas et al. 2017; Stanujkic et al. 2017; Ren, Toniolo 2018). Integration Fuzzy AHP and Fuzzy EDAS is also proposed in (Ecer 2018; Turskis et al. 2017).

Table 7 shows the evaluation of suppliers by three managers based on the linguistic scale. Table 8 shows the elements of the average decision-matrix and the average solution matrix obtained by applying the first and third step of this method. It is important to note that the second criterion, the price of material and the fourth criterion, delivery time, belong to cost criteria, while the other seven belong to useful ones. Having applied Fuzzy EDAS method in Table 9 we have results and final ranking of alternatives. According to the obtained results, the ranking of alternatives is in relation to declining values, so the supplier one represents the best solution, while other suppliers occupy positions as they are listed in the model, and it is important to emphasize that the supplier six has a value close to zero and it is a very bad solution.

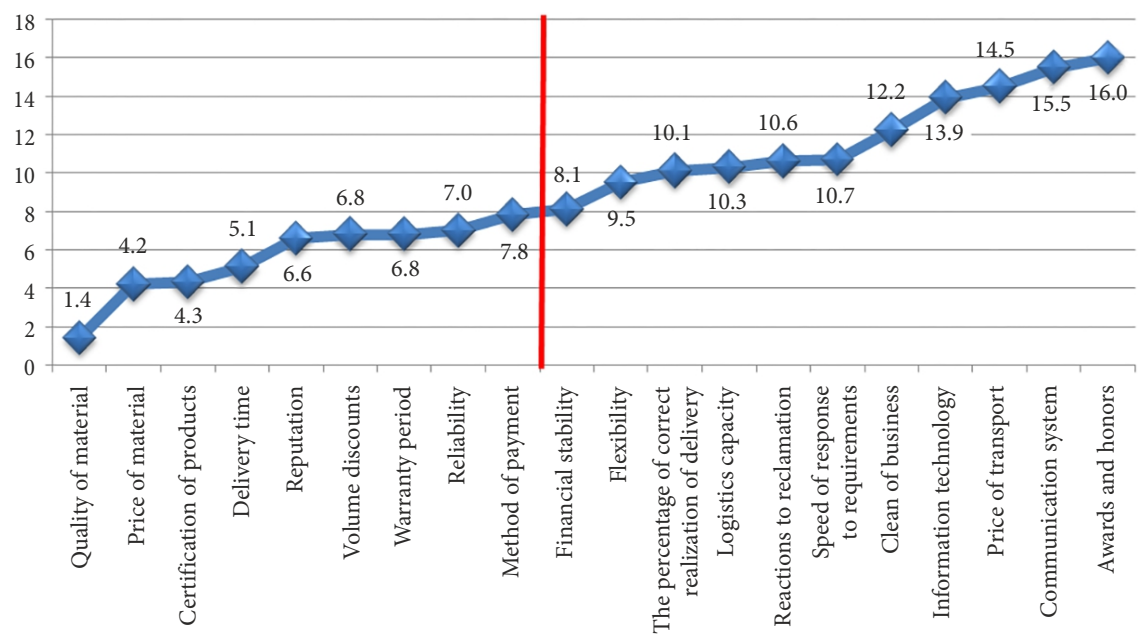

Figure 2. Total ranking of criteria based on their average values in all production area 
Table 7. Evaluation of suppliers based on the linguistic scale

\begin{tabular}{|c|c|c|c|c|c|c|c|c|c|c|}
\hline \multirow{2}{*}{ Expert } & \multirow{2}{*}{ Supplier } & \multicolumn{9}{|c|}{ Criterion } \\
\hline & & $C_{1}$ & $C_{2}$ & $C_{3}$ & $C_{4}$ & $C_{5}$ & $C_{6}$ & $C_{7}$ & $C_{8}$ & $C_{9}$ \\
\hline \multirow[t]{6}{*}{$\overline{E_{1}}$} & $S_{1}$ & $\mathrm{H}$ & $\mathrm{H}$ & $\mathrm{H}$ & $\mathrm{H}$ & $\mathrm{VH}$ & $\mathrm{H}$ & $\mathrm{MH}$ & $\mathrm{H}$ & $\mathrm{VH}$ \\
\hline & $S_{2}$ & $\mathrm{H}$ & $\mathrm{MH}$ & $\mathrm{H}$ & $\mathrm{VH}$ & $\mathrm{H}$ & $\mathrm{M}$ & $\mathrm{MH}$ & $\mathrm{H}$ & $\mathrm{VH}$ \\
\hline & $S_{3}$ & $M$ & $\mathrm{~L}$ & $\mathrm{H}$ & ML & $\mathrm{M}$ & $\mathrm{L}$ & $\mathrm{MH}$ & $\mathrm{L}$ & $\mathrm{MH}$ \\
\hline & $S_{4}$ & $\mathrm{~L}$ & $\mathrm{ML}$ & $\mathrm{M}$ & $\mathrm{ML}$ & $\mathrm{MH}$ & $\mathrm{ML}$ & $\mathrm{M}$ & $\mathrm{M}$ & $\mathrm{M}$ \\
\hline & $S_{5}$ & ML & $\mathrm{M}$ & MH & $\mathrm{M}$ & $\mathrm{L}$ & $\mathrm{M}$ & $\mathrm{MH}$ & $\mathrm{ML}$ & $\mathrm{M}$ \\
\hline & $S_{6}$ & $\mathrm{MH}$ & $\mathrm{MH}$ & $\mathrm{M}$ & $\mathrm{MH}$ & $\mathrm{ML}$ & $\mathrm{VL}$ & ML & ML & $\mathrm{ML}$ \\
\hline \multirow[t]{6}{*}{$E_{2}$} & $S_{1}$ & $\mathrm{H}$ & $\mathrm{MH}$ & $\mathrm{VH}$ & $\mathrm{H}$ & $\mathrm{H}$ & $\mathrm{H}$ & $\mathrm{MH}$ & $\mathrm{VH}$ & $\mathrm{H}$ \\
\hline & $S_{2}$ & $\mathrm{MH}$ & $\mathrm{MH}$ & $\mathrm{H}$ & $\mathrm{VH}$ & $\mathrm{VH}$ & $\mathrm{MH}$ & $\mathrm{MH}$ & $\mathrm{H}$ & $\mathrm{VH}$ \\
\hline & $S_{3}$ & $\mathrm{M}$ & $\mathrm{M}$ & MH & $\mathrm{M}$ & $\mathrm{M}$ & $\mathrm{ML}$ & $\mathrm{MH}$ & $\mathrm{L}$ & $\mathrm{H}$ \\
\hline & $S_{4}$ & $\mathrm{~L}$ & $\mathrm{M}$ & $\mathrm{ML}$ & $\mathrm{ML}$ & $\mathrm{MH}$ & $\mathrm{M}$ & $\mathrm{M}$ & $\mathrm{MH}$ & $\mathrm{M}$ \\
\hline & $S_{5}$ & $\mathrm{~L}$ & $\mathrm{M}$ & $\mathrm{H}$ & $M$ & ML & $\mathrm{M}$ & $\mathrm{M}$ & ML & $\mathrm{MH}$ \\
\hline & $S_{6}$ & $\mathrm{M}$ & $\mathrm{MH}$ & $\mathrm{ML}$ & $\mathrm{MH}$ & $\mathrm{ML}$ & $\mathrm{L}$ & $\mathrm{ML}$ & $\mathrm{M}$ & $\mathrm{ML}$ \\
\hline \multirow[t]{6}{*}{$E_{3}$} & $S_{1}$ & $\mathrm{VH}$ & $\mathrm{MH}$ & $\mathrm{VH}$ & $\mathrm{MH}$ & $\mathrm{H}$ & $\mathrm{VH}$ & $\mathrm{H}$ & $\mathrm{VH}$ & $\mathrm{VH}$ \\
\hline & $S_{2}$ & $\mathrm{H}$ & $\mathrm{H}$ & $\mathrm{MH}$ & $\mathrm{H}$ & $\mathrm{VH}$ & $\mathrm{MH}$ & $\mathrm{H}$ & $\mathrm{H}$ & $\mathrm{VH}$ \\
\hline & $S_{3}$ & $\mathrm{M}$ & ML & $\mathrm{M}$ & $\mathrm{ML}$ & $\mathrm{M}$ & $\mathrm{ML}$ & $\mathrm{H}$ & $\mathrm{ML}$ & $\mathrm{MH}$ \\
\hline & $S_{4}$ & ML & $\mathrm{M}$ & $\mathrm{ML}$ & $\mathrm{L}$ & $\mathrm{H}$ & $\mathrm{M}$ & $\mathrm{ML}$ & $\mathrm{MH}$ & $\mathrm{H}$ \\
\hline & $S_{5}$ & $\mathrm{~L}$ & ML & $\mathrm{H}$ & $\mathrm{ML}$ & $\mathrm{ML}$ & $\mathrm{MH}$ & $\mathrm{M}$ & $\mathrm{L}$ & $\mathrm{MH}$ \\
\hline & $S_{6}$ & $\mathrm{M}$ & $\mathrm{MH}$ & $\mathrm{M}$ & $\mathrm{MH}$ & $\mathrm{M}$ & $\mathrm{ML}$ & $\mathrm{ML}$ & $\mathrm{M}$ & $\mathrm{L}$ \\
\hline
\end{tabular}

Notes: VL - Very Low; L - Low; ML - Medium Low; M - Medium; MH - Medium High; H - High; VH - Very High.

Table 8. The elements of the $A V$-matrix and the average solution matrix

\begin{tabular}{|c|c|c|c|c|c|c|c|c|c|c|c|c|}
\hline \multirow[b]{2}{*}{$C_{1}$} & \multicolumn{4}{|c|}{$A_{1}$} & \multicolumn{4}{|c|}{$A_{6}$} & \multicolumn{4}{|c|}{$\mathrm{AV}$} \\
\hline & 0.73 & 0.83 & 0.87 & 0.93 & 0.43 & 0.53 & 0.57 & 0.67 & 0.41 & 0.51 & 0.54 & 0.64 \\
\hline$C_{2}$ & 0.57 & 0.67 & 0.73 & 0.83 & 0.50 & 0.60 & 0.70 & 0.80 & 0.42 & 0.52 & 0.58 & 0.68 \\
\hline$C_{3}$ & 0.77 & 0.87 & 0.93 & 0.97 & 0.33 & 0.43 & 0.47 & 0.57 & 0.54 & 0.64 & 0.68 & 0.77 \\
\hline$C_{4}$ & 0.63 & 0.73 & 0.77 & 0.87 & 0.50 & 0.60 & 0.70 & 0.80 & 0.45 & 0.55 & 0.61 & 0.70 \\
\hline$C_{5}$ & 0.73 & 0.83 & 0.87 & 0.93 & 0.27 & 0.37 & 0.43 & 0.53 & 0.51 & 0.61 & 0.66 & 0.74 \\
\hline$C_{6}$ & 0.73 & 0.83 & 0.87 & 0.93 & 0.10 & 0.17 & 0.23 & 0.33 & 0.37 & 0.47 & 0.52 & 0.61 \\
\hline $\mathrm{C}_{7}$ & 0.57 & 0.67 & 0.73 & 0.83 & 0.20 & 0.30 & 0.40 & 0.50 & 0.45 & 0.55 & 0.61 & 0.71 \\
\hline $\mathrm{C}_{8}$ & 0.77 & 0.87 & 0.93 & 0.97 & 0.33 & 0.43 & 0.47 & 0.57 & 0.43 & 0.53 & 0.57 & 0.66 \\
\hline $\mathrm{C}_{9}$ & 0.77 & 0.87 & 0.93 & 0.97 & 0.17 & 0.27 & 0.33 & 0.43 & 0.55 & 0.65 & 0.70 & 0.78 \\
\hline
\end{tabular}

Table 9. The weighted sum and the appraisal scores

\begin{tabular}{|c|c|c|c|c|c|c|}
\hline & $\widetilde{s p_{i}}$ & $\widetilde{s n_{i}}$ & $\widetilde{n s p_{i}}$ & $\widetilde{n_{s n_{i}}}$ & $\widetilde{\tilde{a s}_{i}}$ & $k\left(\widetilde{a s}_{i}\right)$ \\
\hline$A_{1}$ & $\begin{array}{l}0.06,0.31, \\
0.43,0.64)\end{array}$ & $\begin{array}{c}(-0.05,0.05 \\
0.11,0,20)\end{array}$ & $\begin{array}{l}(0.17,0.87, \\
1.21,1.79)\end{array}$ & $\begin{array}{c}0.021,0.59 \\
0.80,1.17)\end{array}$ & $\begin{array}{l}(0.19,0.73, \\
1.00,1.48)\end{array}$ & 0.85 \\
\hline$A_{2}$ & $\begin{array}{c}(-0.08,0.17 \\
0.29,0.54)\end{array}$ & $\begin{array}{c}(-0.02,0.08 \\
0.14,0.22)\end{array}$ & $\begin{array}{c}(-0.21,0.49 \\
0.82,1.51)\end{array}$ & $\begin{array}{l}(0.13,0.47 \\
0.70,1.07)\end{array}$ & $\begin{array}{c}(-0.04,0.48 \\
0.76,1.29)\end{array}$ & 0.62 \\
\hline$A_{3}$ & $\begin{array}{c}(-0.06,0.08 \\
0.15,0.29)\end{array}$ & $\begin{array}{c}(-0.12,0.10 \\
0.17,0.38)\end{array}$ & $\begin{array}{c}(-0.16,0.22 \\
0.43,0.81)\end{array}$ & $\begin{array}{c}(-0.49,0.33 \\
0.63,1.48)\end{array}$ & $\begin{array}{c}-0.33,0.27 \\
0.53,1.15)\end{array}$ & 0.41 \\
\hline$A_{4}$ & $\begin{array}{c}(-0.10,0.06 \\
0.14,0.30)\end{array}$ & $\begin{array}{c}(-0.07,0.12 \\
0.20,0.39)\end{array}$ & $\begin{array}{c}(-0.28,0.16 \\
0.40,0.85)\end{array}$ & $\begin{array}{c}(-0.53,0.21 \\
0.53,1.29)\end{array}$ & $\begin{array}{c}(-0.40,0.19 \\
0.47,1.07)\end{array}$ & 0.33 \\
\hline$A_{5}$ & $\begin{array}{c}(-0.14,0.04 \\
0.13,0.32)\end{array}$ & $\begin{array}{c}(-0.04,0.13 \\
0.21,0.37)\end{array}$ & $\begin{array}{c}(-0.40,0.12 \\
0.36,0.88)\end{array}$ & $\begin{array}{c}(-0.43,0.20 \\
0.49,1.15)\end{array}$ & $\begin{array}{c}(-0.42,0.16 \\
0.43,1.02)\end{array}$ & 0.30 \\
\hline$A_{6}$ & $\begin{array}{c}(-0.07,0.00 \\
0.02,0.09)\end{array}$ & $\begin{array}{c}(-0.12,0.17 \\
0.35,0.63)\end{array}$ & $\begin{array}{c}(-0.19,-0.01 \\
0.06,0.25)\end{array}$ & $\begin{array}{c}(-1.43,-0.37 \\
0.34,1.46)\end{array}$ & $\begin{array}{c}(-0.81,-0.19 \\
0.20,0.85)\end{array}$ & 0.01 \\
\hline
\end{tabular}




\subsection{Sensitivity analysis}

After presenting the results, it is necessary to determine the stability of the model and the sensitivity of the results to the change in the significance of particular criteria. Therefore, a sensitivity analysis has been performed, which is presented throughout three parts. Figure 3 shows simulated values of all criteria in 15 different sets. Figure 4 shows the values of all suppliers throughout different scenarios, while Figure 5 shows the ranking of alternatives in all scenarios.

Figure 3 shows sets of sensitivity analysis and simulated criteria values throughout each set. In the first nine sets, one criterion starting from the first one increases by $12 \%$, while the other criteria are reduced by $1.5 \%$ in order to satisfy the condition that the sum of the values of all the criteria still remains one. In set 10 , all criteria have the same value, in set 11, the first four criteria are reduced by $10 \%$, while the other five criteria increase by $8 \%$. The most important criteria $C_{1}, C_{2}$ and $C_{6}$ in set 12 are reduced by $12 \%$, while the value of the other six criteria increases by $6 \%$. In set 13 , the values of 0.200 are assigned to the least significant $C_{5}, C_{7}, C_{8}$ and $C_{9}$ criteria, while the other criteria obtain the value of 0.040 . In set 14 , the least significant $C_{5}, C_{8}$ and $C_{9}$ criteria increase their values by even $20 \%$, while the others reduce the values by $10 \%$ and in the last set 15 , the first three criteria have a value of 0.221 , while the others have 0.056 .

Figure 4 shows the results of the sensitivity analysis and the values that each supplier has in the formed sets. With the increase in the value of the first criterion, the suppliers four, five and six have very low values and in that case, they can be immediately eliminated as inappropriate. By increasing the second criterion, the value of the third supplier grows and approaches the value of the second one, while the values of the fourth and fifth suppliers are also approximate. The certification of products as the third criterion significantly affects suppliers five and four who exchange the positions they occupy in this set. As the importance of delivery time criterion increases, the supplier three acquires the highest importance and occupies the second position in the overall ranking. In sets five and six, the suppliers three and four have identical values, while in set seven the significance of the fifth supplier increases. In the next set, the value of the fourth supplier increases that exchange the position with the third one. There are no significant changes in the sets nine and 10 , and the results are almost identical to those in the model. By reducing the significance of the first four criteria, and increasing the others, the alternative four increases and occupies the third position, while the alternative five is in the fourth and the alternative three is in the fifth position. In the remaining sets, no significant changes are made either.

As it can be seen in Figure 5, the stability of the model does not come into question, since the supplier one in all formed sets represents the best solution and its value throughout the sets is in the range of $0.78 \ldots 0.97$. The supplier two has only lost the fourth position in the set four,

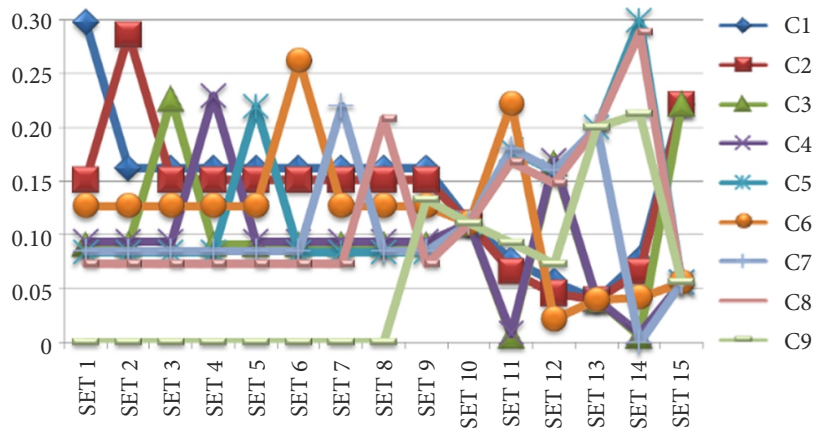

Figure 3. Simulated values of criteria

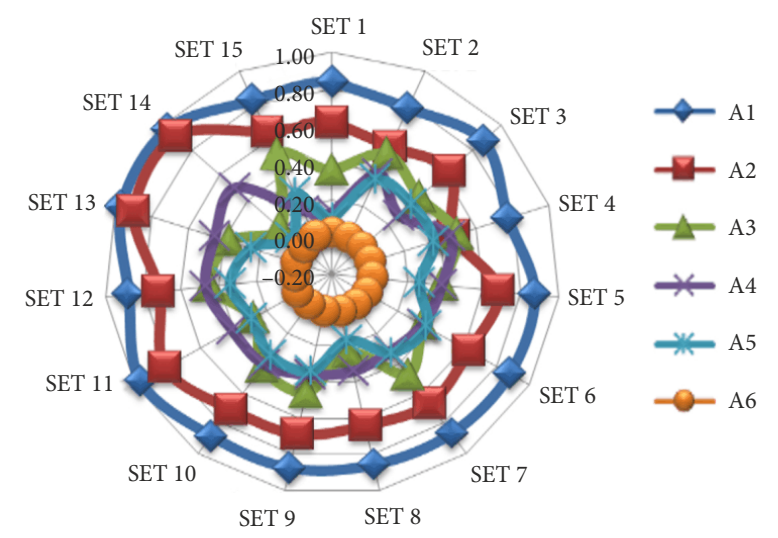

Figure 4. Results of sensitivity analysis

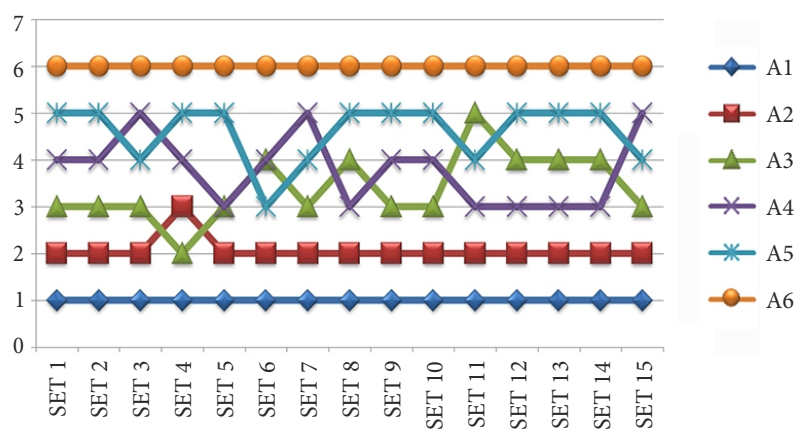

Figure 5. Ranking of suppliers in the sensitivity analysis

which additionally confirms the validity, i.e., the stability of the model. The supplier six has proved to be the most unsuitable and it is always the worst solution. More important changes in the sensitivity analysis are not visible, since even when a change in ranking occurs, there are no drastic changes. The supplier three is in more than $50 \%$ of cases at the position three, once it is placed at the second and fifth position, while in the other five sets it is in the fourth place. The suppliers four and five mostly exchange positions four and five.

\section{Conclusions}

The research presented in this paper lasted more than a year. The paper proposes the model for evaluating suppliers in production companies, which in its initial stage consists of twenty criteria. Applying the knowledge of 
managers from the mentioned fields, the set of criteria, using the Fuzzy AHP method, has been modified to a total of nine, and it has been verified in the case of the selection of suppliers in a company for the production of plastic bags and foils. The proposed model is the integration of the Fuzzy AHP and Fuzzy EDAS methods, where the Fuzzy AHP is used to obtain weight values, and the Fuzzy EDAS to select suppliers. The results obtained by applying this model show that the supplier one is the best solution, even in all scenarios that imply different values of criteria, which means that it is completely insensitive to the significance of the criteria. In accordance with the problem setting, the development of an integrated evaluation model and supplier selection, it can be highlight several of the most important tasks that have been performed. The first is the analysis of the current situation and previous research in the field with a review of the situation in developing countries. The conducted review provided data showing the actuality of the topic and the need for further research. The second task is a confirmation of the possibility of improving the supply chain parts in terms of evaluating and selecting the best supplier using a combination of MCDM and fuzzy set theory. The third task that has been performed is the development of the integrated model for supplier evaluation in supply chains that reduce the subjectivity and imprecision that occur every day in decision-making. In addition, the proven applicability of the developed an integrated model for supplier evaluation under the current conditions prevailing in the observed supply chains has been demonstrated.

Contribution of this model is that with certain modifications, this model could be applied to almost all production activities, regardless of the marketplace where the producers and suppliers exist. In addition, the flexibility of the model is reflected in the fact that its verification can be carried out by integrating any of the MCDM methods. In its original form it is recommended for the markets of developing countries, because within it there are criteria that are specific for those markets, which represents one of the limitations of this model.

Future research related to this paper refers to the possibility of forming a similar model including managers from production activities of many countries operating on different continents.

\section{Contribution}

Each author has participated and contributed sufficiently to take public responsibility for appropriate portions of the content.

\section{Disclosure statement}

The authors declare no conflict of interest.

\section{References}

Asamoah, D.; Annan, J.; Nyarko, S. 2012. AHP approach for supplier evaluation and selection in a pharmaceutical manufacturing firm in Ghana, International Journal of Business and Management 7(10): 49-62.

https://doi.org/10.5539/ijbm.v7n10p49

Badi, I.; Abdulshahed, A. M.; Shetwan, A. 2018. A case study of supplier selection for a steelmaking company in Libya by using the combinative distance-based assessment (CODAS) model, Decision Making: Applications in Management and Engineering 1(1): 1-12. https://doi.org/10.31181/dmame180101b

Baležentis, A.; Baležentis, T. 2011. An innovative multi-criteria supplier selection based on two-tuple MULTIMOORA and hybrid data, Economic Computation and Economic Cybernetics Studies and Research 45(2): 37-56.

Ballı, S.; Korukoğlu, S. 2009. Operating system selection using fuzzy AHP and TOPSIS methods, Mathematical and Computational Applications 14(2): 119-130. https://doi.org/10.3390/mca14020119

Birgün Barla, S. 2003. A case study of supplier selection for lean supply by using a mathematical model, Logistics Information Management 16(6): 451-459.

https://doi.org/10.1108/09576050310503420

Božanić, D.; Tešić, D.; Milićević, J. 2018. A hybrid fuzzy AHPMABAC model: application in the Serbian army - the selection of the location for deep wading as a technique of crossing the river by tanks, Decision Making: Applications in Management and Engineering 1(1): 143-164.

https://doi.org/10.31181/dmame1801143b

Bronja, Harun; Bronja, Haris. 2015. Two-phase selection procedure of aluminized sheet supplier by applying fuzzy AHP and fuzzy TOPSIS methodology, Tehnički vjesnik 22(4): 821-828. https://doi.org/10.17559/TV-20140203122653

Büyüközkan, G.; Göçer, F. 2017. Application of a new combined intuitionistic fuzzy MCDM approach based on axiomatic design methodology for the supplier selection problem, Applied Soft Computing 52: 1222-1238.

https://doi.org/10.1016/j.asoc.2016.08.051

Çebi, F.; Bayraktar, D. 2003. An integrated approach for supplier selection, Logistics Information Management 16(6): 395-400. https://doi.org/10.1108/09576050310503376

Chamodrakas, I.; Batis, D.; Martakos, D. 2010. Supplier selection in electronic marketplaces using satisficing and fuzzy AHP, Expert Systems with Applications 37(1): 490-498. https://doi.org/10.1016/j.eswa.2009.05.043

Chan, F. T. S.; Kumar, N. 2007. Global supplier development considering risk factors using fuzzy extended AHP-based approach, Omega 35(4): 417-431. https://doi.org/10.1016/j.omega.2005.08.004

Chang, D.-Y. 1996. Applications of the extent analysis method on fuzzy AHP, European Journal of Operational Research 95(3): 649-655. https://doi.org/10.1016/0377-2217(95)00300-2

Chen, C.-T.; Lin, C.-T.; Huang, S.-F. 2006. A fuzzy approach for supplier evaluation and selection in supply chain management, International Journal of Production Economics 102(2): 289-301. https://doi.org/10.1016/j.ijpe.2005.03.009

Chen, N.; Xu, Z.; Xia, M. 2015. The ELECTRE I multi-criteria decision-making method based on hesitant fuzzy sets, International Journal of Information Technology \& Decision Making 14(3): 621-657. https://doi.org/10.1142/S0219622014500187 
Chiouy, C.-Y.; Chou, S.-H.; Yeh, C.-Y. 2011. Using fuzzy AHP in selecting and prioritizing sustainable supplier on CSR for Taiwan's electronics industry, Journal of Information and $O p$ timization Sciences 32(5): 1135-1153.

https://doi.org/10.1080/02522667.2011.10700110

Dickson, G. W. 1966. An analysis of vendor selection systems and decisions, Journal of Purchasing 2(1): 5-17. https://doi.org/10.1111/j.1745-493X.1966.tb00818.x

Ecer, F. 2018. Third-party logistics (3Pls) provider selection via Fuzzy AHP and EDAS integrated model, Technological and Economic Development of Economy 24(2): 615-634. https://doi.org/10.3846/20294913.2016.1213207

Ellram, L. M. 1990. The supplier selection decision in strategic partnerships, Journal of Supply Chain Management 26(4): 8-14. https://doi.org/10.1111/j.1745-493X.1990.tb00515.x

Eraslan, E.; Atalay, K. D. 2014. A comparative holistic fuzzy approach for evaluation of the chain performance of suppliers, Journal of Applied Mathematics 2014: 1-9. https://doi.org/10.1155/2014/109821

Fallahpour, A.; Olugu, E. U.; Musa, S. N. 2017. A hybrid model for supplier selection: integration of AHP and multi expression programming (MEP), Neural Computing and Applications 28(3): 499-504.

https://doi.org/10.1007/s00521-015-2078-6

Gencer, C.; Gürpinar, D. 2007. Analytic network process in supplier selection: A case study in an electronic firm, Applied Mathematical Modelling 31(11): 2475-2486.

https://doi.org/10.1016/j.apm.2006.10.002

Guo, X.; Yuan, Z.; Tian, B. 2009. Supplier selection based on hierarchical potential support vector machine, Expert Systems with Applications 36(3): 6978-6985.

https://doi.org/10.1016/j.eswa.2008.08.074

Hashemian, S. M.; Behzadian, M.; Samizadeh, R.; Ignatius, J. 2014. A fuzzy hybrid group decision support system approach for the supplier evaluation process, The International Journal of Advanced Manufacturing Technology 73(5-8): 1105-1117. https://doi.org/10.1007/s00170-014-5843-2

Hashemkhani Zolfani, S.; Sedaghat, M.; Zavadskas, E. K. 2012. Performance evaluating of rural ICT centers (telecenters), applying fuzzy AHP, SAW-G and TOPSIS Grey, a case study in Iran, Technological and Economic Development of Economy 18(2): 364-387. https://doi.org/10.3846/20294913.2012.685110

Ho, W.; Xu, X.; Dey, P. K. 2010. Multi-criteria decision making approaches for supplier evaluation and selection: a literature review, European Journal of Operational Research 202(1): 1624. https://doi.org/10.1016/j.ejor.2009.05.009

Hruška, R.; Průša, P.; Babić, D. 2014. The use of AHP method for selection of supplier, Transport 29(2): 195-203.

https://doi.org/10.3846/16484142.2014.930928

Hudymáčová, M.; Benková, M.; Pócsová, J.; Škovránek, T. 2010. Supplier selection based on multi-criterial AHP method, Acta Montanistica Slovaca 15(3): 249-255.

Jafarnejad, A.; Salimi, M. 2013. Grey TOPSIS method for supplier selection with literature and Delphi criteria in an auto company, Academia Arena 5(12): 40-46.

Jain, V.; Sangaiah, A. K.; Sakhuja, S.; Thoduka, N.; Aggarwal, R. 2018. Supplier selection using fuzzy AHP and TOPSIS: a case study in the Indian automotive industry, Neural Computing and Applications 29(7): 555-564.

https://doi.org/10.1007/s00521-016-2533-z

Jamil, N.; Besar, R.; Sim, H. K. 2013. A study of multicriteria decision making for supplier selection in automotive industry, Journal of Industrial Engineering 2013: 1-22. https://doi.org/10.1155/2013/841584
Kabi, A. A.; Hussain, M.; Khan, M. 2017. Assessment of supplier selection for critical items in public organisations of Abu Dhabi, World Review of Science, Technology and Sustainable Development 13(1): 56-73.

https://doi.org/10.1504/WRSTSD.2017.083710

Kahraman, C.; Cebeci, U.; Ulukan, Z. 2003. Multi-criteria supplier selection using fuzzy AHP, Logistics Information Management 16(6): 382-394. https://doi.org/10.1108/09576050310503367

Kahraman, C.; Keshavarz Ghorabaee, M.; Zavadskas, E. K.; Cevik Onar, S.; Yazdani, M.; Oztaysi, B. 2017. Intuitionistic fuzzy EDAS method: an application to solid waste disposal site selection, Journal of Environmental Engineering and Landscape Management 25(1): 1-12.

https://doi.org/10.3846/16486897.2017.1281139

Kannan, V. R.; Tan, K. C. 2006. Buyer-supplier relationships: the impact of supplier selection and buyer-supplier engagement on relationship and firm performance, International Journal of Physical Distribution \& Logistics Management 36(10): 755775. https://doi.org/10.1108/09600030610714580

Karabašević, D., Stanujkić, D., Đorđević, B., \& Stanujkić, A. 2018. The weighted sum preferred levels of performances approach to solving problems in human resources management. Serbian Journal of Management, 13(1), 145-156. https://doi.org/10.5937/sjm13-12589

Keshavarz Ghorabaee, M.; Amiri, M.; Zavadskas, E. K.; Antuchevičienè, J. 2018a. A new hybrid fuzzy MCDM approach for evaluation of construction equipment with sustainability considerations, Archives of Civil and Mechanical Engineering 18(1): 32-49.

https://doi.org/10.1016/j.acme.2017.04.011

Keshavarz-Ghorabaee, M.; Amiri, M.; Zavadskas, E. K.; Turskis, Z.; Antuchevičienè, J. 2018b. A dynamic fuzzy approach based on the EDAS method for multi-criteria subcontractor evaluation, Information 9(3): 68.

https://doi.org/10.3390/info9030068

Keshavarz Ghorabaee, M.; Amiri, M.; Olfat, L.; Khatami Firouzabadi, S. A. 2017a. Designing a multi-product multi-period supply chain network with reverse logistics and multiple objectives under uncertainty, Technological and Economic Development of Economy 23(3): 520-548. https://doi.org/10.3846/20294913.2017.1312630

Keshavarz Ghorabaee, M.; Amiri, M.; Zavadskas, E. K.; Antuchevičienè, J. 2017b. Supplier evaluation and selection in fuzzy environments: a review of MADM approaches, Economic Research - Ekonomska Istraživanja 30: 1073-1118. https://doi.org/10.1080/1331677X.2017.1314828

Keshavarz Ghorabaee, M.; Amiri, M.; Zavadskas, E. K.; Turskis, Z. 2017c. Multi-criteria group decision-making using an extended EDAS method with interval type-2 fuzzy sets, E\&M. Ekonomie a Management 20(1): 48-68. https://doi.org/10.15240/tul/001/2017-1-004

Keshavarz Ghorabaee, M.; Zavadskas, E. K.; Amiri, M.; Turskis, Z. 2016. Extended EDAS method for fuzzy multi-criteria decision-making: an application to supplier selection, International Journal of Computers Communications \& Control 11(3): 358-371. https://doi.org/10.15837/ijccc.2016.3.2557

Keshavarz Ghorabaee, M.; Zavadskas, E. K.; Olfat, L.; Turskis, Z. 2015. Multi-criteria inventory classification using a new method of evaluation based on distance from average solution (EDAS), Informatica 26(3): 435-451.

https://doi.org/10.15388/Informatica.2015.57

Khorasani, O.; Bafruei, M. K. 2011. A fuzzy AHP approach for evaluating and selecting supplier in pharmaceutical industry, International Journal of Academic Research 3(1): 346-352. 
Kilic, H. S. 2013. An integrated approach for supplier selection in multi-item/multi-supplier environment, Applied Mathematical Modelling 37(14-15): 7752-7763.

https://doi.org/10.1016/j.apm.2013.03.010

Kilincci, O.; Onal, S. A. 2011. Fuzzy AHP approach for supplier selection in a washing machine company, Expert Systems with Applications 38(8): 9656-9664.

https://doi.org/10.1016/j.eswa.2011.01.159

Kwong, C. K.; Bai, H. 2003. Determining the importance weights for the customer requirements in QFD using a fuzzy AHP with an extent analysis approach, IIE Transactions 35(7): 619-626. https://doi.org/10.1080/07408170304355

Lam, K.-C.; Tao, R.; Lam, M. C.-K. 2010. A material supplier selection model for property developers using fuzzy principal component analysis, Automation in Construction 19(5): 608-618. https://doi.org/10.1016/j.autcon.2010.02.007

Lee, A. H. I. 2009. A fuzzy supplier selection model with the consideration of benefits, opportunities, costs and risks, Expert Systems with Applications 36(2): 2879-2893.

https://doi.org/10.1016/j.eswa.2008.01.045

Liao, C.-N.; Fu, Y.-K.; Wu, L.-C. 2016. Integrated FAHP, ARAS-F and MSGP methods for green supplier evaluation and selection, Technological and Economic Development of Economy 22(5): 651-669. https://doi.org/10.3846/20294913.2015.1072750

Lima Junior, F. R.; Osiro, L.; Carpinetti, L. C. R. 2014. A comparison between Fuzzy AHP and Fuzzy TOPSIS methods to supplier selection, Applied Soft Computing 21: 194-209. https://doi.org/10.1016/j.asoc.2014.03.014

Lin, H.-T.; Chang, W.-L. 2008. Order selection and pricing methods using flexible quantity and fuzzy approach for buyer evaluation, European Journal of Operational Research 187(2): 415-428. https://doi.org/10.1016/j.ejor.2007.03.003

Mahmoodzadeh, S.; Shahrabi, J.; Pariazar, M.; Zaeri, M. S. 2007. Project selection by using fuzzy AHP and TOPSIS technique, International Journal of Social, Behavioral, Educational, Economic, Business and Industrial Engineering 1(6): 270-275.

Mardani, A.; Jusoh, A.; Nor, K.; Khalifah, Z.; Zakwan, N.; Valipour, A. 2015. Multiple criteria decision-making techniques and their applications - a review of the literature from 2000 to 2014, Economic Research - Ekonomska Istraživanja 28: 516-571. https://doi.org/10.1080/1331677X.2015.1075139

Mehralian, G.; Gatari, A. R.; Morakabati, M.; Vatanpour, H. 2012. Developing a suitable model for supplier selection based on supply chain risks: an empirical study from Iranian pharmaceutical companies, Iranian Journal of Pharmaceutical Research 11(1): 209-219.

Min, H.; Galle, W. P. 1999. Electronic commerce usage in business-to-business purchasing, International Journal of Operations \& Production Management 19(9): 909-921. https://doi.org/10.1108/01443579910280232

Muralidharan, C.; Anantharaman, N.; Deshmukh, S. G. 2002. A multi-criteria group decisionmaking model for supplier rating, Journal of Supply Chain Management 38(3): 22-33. https://doi.org/10.1111/j.1745-493X.2002.tb00140.x

Özbek, A. 2015. Supplier selection with fuzzy TOPSIS, Journal of Economics and Sustainable Development 6(18): 114-125.

Pamučar, D.; Stević, Ž.; Zavadskas, E. K. 2018. Integration of interval rough AHP and interval rough MABAC methods for evaluating university web pages, Applied Soft Computing 67: 141-163. https://doi.org/10.1016/j.asoc.2018.02.057

Parthiban, P.; Zubar, H. A.; Garge, C. P. 2012. A multi criteria decision making approach for suppliers selection, Procedia Engineering 38: 2312-2328.

https://doi.org/10.1016/j.proeng.2012.06.277
Pi, W.-N.; Low, C. 2006. Supplier evaluation and selection via Taguchi loss functions and an AHP, The International Journal of Advanced Manufacturing Technology 27(5-6): 625-630. https://doi.org/10.1007/s00170-004-2227-z

Ren, J.; Toniolo, S. 2018. Life cycle sustainability decision-support framework for ranking of hydrogen production pathways under uncertainties: an interval multi-criteria decision making approach, Journal of Cleaner Production 175: 222236. https://doi.org/10.1016/j.jclepro.2017.12.070

Rezaei, J.; Fahim, P. B. M.; Tavasszy, L. 2014. Supplier selection in the airline retail industry using a funnel methodology: Conjunctive screening method and fuzzy AHP, Expert Systems with Applications 41(18): 8165-8179.

https://doi.org/10.1016/j.eswa.2014.07.005

Saad, S. M.; Kunhu, N.; Mohamed, A. M. 2016. A fuzzy-AHP multi-criteria decision-making model for procurement process, International Journal of Logistics Systems and Management 23(1): 1-24. https://doi.org/10.1504/IJLSM.2016.073295

Simpson, P. M.; Siguaw, J. A.; White, S. C. 2002. Measuring the performance of suppliers: an analysis of evaluation processes, Journal of Supply Chain Management 38(4): 29-41. https://doi.org/10.1111/j.1745-493X.2002.tb00118.x

Singh, R.; Rajput, H.; Chaturvedi, V.; Vimal, J. 2012. Supplier selection by technique of order preference by similarity to ideal solution (TOPSIS) method for automotive industry, International Journal of Advanced Technology \& Engineering Research 2(2): 157-160.

Stanujkic, D.; Zavadskas, E. K.; Keshavarz Ghorabaee, M.; Turskis, Z. 2017. An extension of the EDAS method based on the use of interval grey numbers, Studies in Informatics and Control 26(1): 5-12. https://doi.org/10.24846/v26ily201701

Stević, Ž.; Pamučar, D.; Vasiljević, M.; Stojić, G.; Korica, S. 2017a. Novel integrated multi-criteria model for supplier selection: case study construction company, Symmetry 9(11): 279. https://doi.org/10.3390/sym9110279

Stević, Ž.; Pamučar, D.; Zavadskas, E. K.; Ćirović, G.; Prentkovskis, O. 2017b. The selection of wagons for the internal transport of a logistics company: a novel approach based on rough BWM and rough SAW methods, Symmetry 9(11): 264. https://doi.org/10.3390/sym9110264

Stević, Ž.; Tanackov, I.; Vasiljević, M.; Novarlić, B.; Stojić, G. 2016. An integrated fuzzy AHP and TOPSIS model for supplier evaluation, Serbian Journal of Management 11(1): 15-27. https://doi.org/10.5937/sjm11-10452

Sun, C.-C. 2010. A performance evaluation model by integrating fuzzy AHP and fuzzy TOPSIS methods, Expert Systems with Applications 37(12): 7745-7754. https://doi.org/10.1016/j.eswa.2010.04.066

Tam, M. C. Y.; Tummala, V. M. R. 2001. An application of the AHP in vendor selection of a telecommunications system, Omega 29(2): 171-182.

https://doi.org/10.1016/S0305-0483(00)00039-6

Ting, S.-C.; Cho, D.-I. 2008. An integrated approach for supplier selection and purchasing decisions, Supply Chain Management: an International Journal 13(2): 116-127. https://doi.org/10.1108/13598540810860958

Triantaphyllou, E.; Mann, S. H. 1995. Using the analytic hierarchy process for decision making in engineering applications: some challenges, International Journal of Industrial Engineering: Theory, Applications and Practice 2(1): 35-44.

Turskis, Z.; Juodagalvienė, B. 2016. A novel hybrid multi-criteria decision-making model to assess a stairs shape for dwelling houses, Journal of Civil Engineering and Management 22(8): 1078-1087. https://doi.org/10.3846/13923730.2016.1259179 
Turskis, Z.; Keršuliene, V.; Vinogradova, I. 2017. A new fuzzy hybrid multi-criteria decision-making approach to solve personnel assessment problems. Case study: director selection for estates and economy office, Economic Computation and Economic Cybernetics Studies and Research 51(3): 211-229.

Turskis, Z.; Zavadskas, E. K.; Antuchevičienė, J.; Kosareva, N. 2015. A hybrid model based on fuzzy AHP and fuzzy WASPAS for construction site selection, International Journal of Computers Communications \& Control 10(6): 873-888. https://doi.org/10.15837/ijccc.2015.6.2078

Uygun, Ö.; Kaçamak, H.; Ayşim, G.; Şimşir, F. 2013. Supplier selection for automotive industry using multi-criteria decision making techniques, TOJSAT: The Online Journal of Science and Technology 3(4): 126-137.

Wang, G.; Huang, S. H.; Dismukes, J. P. 2004. Product-driven supply chain selection using integrated multi-criteria decision-making methodology, International Journal of Production Economics 91(1): 1-15. https://doi.org/10.1016/S0925-5273(03)00221-4

Wang, T.-K.; Zhang, Q.; Chong, H.-Y.; Wang, X. 2017. Integrated supplier selection framework in a resilient construction supply chain: an approach via analytic hierarchy process (AHP) and grey relational analysis (GRA), Sustainability 9(2): 289. https://doi.org/10.3390/su9020289

Wang, W.-P. 2010. A fuzzy linguistic computing approach to supplier evaluation, Applied Mathematical Modelling 34(10): 3130-3141. https://doi.org/10.1016/j.apm.2010.02.002

Weber, C. A.; Current, J. R.; Benton, W. C. 1991. Vendor selection criteria and methods, European Journal of Operational Research 50(1): 2-18. https://doi.org/10.1016/0377-2217(91)90033-R

Yücenur, G. N.; Vayvay, Ö.; Demirel, N. Ç. 2011. Supplier selection problem in global supply chains by AHP and ANP approaches under fuzzy environment, The International Journal of Advanced Manufacturing Technology 56(5-8): 823-833. https://doi.org/10.1007/s00170-011-3220-y

Zadeh, L. A. 1965. Fuzzy sets, Information and Control 8(3): 338-353. https://doi.org/10.1016/S0019-9958(65)90241-X

Zavadskas, E. K.; Cavallaro, F.; Podvezko, V.; Ubartè, I.; Kaklauskas, A. 2017. MCDM assessment of a healthy and safe built environment according to sustainable development principles: a practical neighborhood approach in Vilnius, Sustainability 9(5): 702. https://doi.org/10.3390/su9050702

Zavadskas, E. K.; Turskis, Z.; Kildienè, S. 2014. State of art surveys of overviews on MCDM/MADM methods, Technological and Economic Development of Economy 20(1): 165-179. https://doi.org/10.3846/20294913.2014.892037

Zeydan, M.; Çolpan, C.; Çobanoğlu, C. 2011. A combined methodology for supplier selection and performance evaluation, Expert Systems with Applications 38(3): 2741-2751.

https://doi.org/10.1016/j.eswa.2010.08.064 